\title{
Research Paper: \\ Ameliorative Effect of Trevo Dietary Supplement Against Lead Acetate Nephrotoxicity
}

\author{
Omotayo B. Ilesanmi ${ }^{1 *}$ (D), Eni-yimini Solomon Agoro ${ }^{1}$ (1)
}

1. Department of Biochemistry, Faculty of Science, Federal University Otuoke, Bayelsa State, Nigeria.

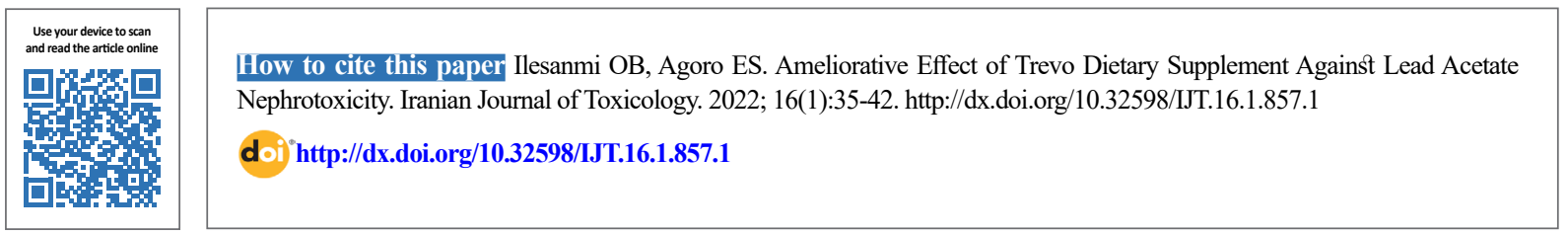

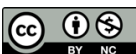

Article info:

Received: 24 Jul 2021

Accepted: 09 Nov 2021

Online Published: 01 Jan 2022

*Corresponding author:

Omotayo B. Ilesanmi, PhD.

Address: Department of Biochemistry,

Faculty of Science, Federal Univer-

sity Otuoke, Bayelsa State, Nigeria.

E-mail: ilesanmiob@fuotuoke.edu.ng

\section{ABSTRACT}

Background: Trevo is a nutritional supplement with numerous bioactive natural products, with detoxifying and antioxidant properties. The purpose of this study was to investigate the ability of Trévo to protect against oxidative stress induced by lead in the kidneys of male Wistar rats.

Methods: Thirty-five healthy male Wistar rats were divided into five groups of seven rats each, using a randomized design. $\mathrm{I}=$ control; $\mathrm{II}=15 \mathrm{mg} / \mathrm{kg}$ of lead acetate $(\mathrm{PbA}) ; \mathrm{III}=2 \mathrm{ml} /$ $\mathrm{kg}$ of trevo $+\mathrm{PbA} ; \mathrm{IV}=5 \mathrm{ml} / \mathrm{kg}$ of trevo $+\mathrm{PbA} ; \mathrm{V}=5 \mathrm{ml} / \mathrm{kg}$ of trevo. Animals were treated with trevo for five days before co-administration with lead intraperitoneally for 10 consecutive days. Animals were sacrificed $24 \mathrm{hr}$ after the last administration, blood samples were collected via cardiac puncture, and processed for assessment of urea, creatinine, and uric acid (UA), while the kidney samples were excised and processed for the following biochemical assays: Malondialdehyde (MDA), Glutathione-S-Transferase (GST), Catalase (CAT), Superoxide Dismutase (SOD), and Reduced Glutathione (GSH).

Results: Injection of PbA caused a significant increase in the serum levels of urea, creatinine, and uric acid, and a significant increase $(\mathrm{P}<0.001)$ in the MDA concentration, and decreases in GSH concentration, CAT, SOD, and GST activities $(\mathrm{P}<0.05)$ as compared to the controls. Pretreatment with trevo prevented the oxidative stress induced by lead acetate in the kidney tissue samples and improve the renal function. The protective effect was evident at $5 \mathrm{ml} / \mathrm{kg}$ of trevo.

Conclusion: The results showed that trevo was nephroprotective against lead toxicity and the activity might be linked to the presence of numerous antioxidant phytochemicals present in trevo.

Keywords: Lead, Nephrotoxicity, Oxidative stress, Reactive oxygen species, Natural product

\section{Introduction}

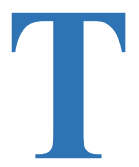

he ubiquitous nature of lead has made it one of the most studied heavy metals. Lead is an environmental pollutant that is nonbiodegradable with a very long half-life, thus, it can stay in the environment for a long time undetected unless it is present in high concentrations. Human activities have further increased the concentration of lead in the atmosphere
[1-3]. Industrial growth in automobiles, electrical, agricultural, and construction industries contribute to the observed increased concentration of lead in the environment [1]. The toxic effects of lead have been reported in the organs of experimental animals [4-6]. Lead has been reported to damage the nervous, reproductive, hematopoietic, respiratory and excretory systems, such as kidneys and liver [7-10]. Kidneys are particularly prone to the toxic effect of lead, since they play an important role in its excretion $[4,11,12]$. Biologically, lead has 
no health benefit to humans; however, its bioaccumulation in the body leads to various injuries as stated earlier [13]. The presence of non-enzymatic proteins with high affinities for lead in the kidneys also increases their susceptibility to its toxicity $[14,15]$. Morphologically, lead has been reported to cause interstitial lesions, glomerular sclerosis, fibrosis, and nephropathy.

One of the agreed upon mechanisms of lead-induced nephrotoxicity is oxidative stress [16]. The idea is to look for safe and effective antioxidant natural compounds to counter lead poisoning. Lead is known to alter the redox mechanism in the kidneys, thereby increasing Reactive Oxygen Species (ROS) and diminishing the antioxidant systems [17]. The common treatment for lead poisoning is through the use of metal chelators. Some of the approved treatments include dimercaprol dimercaptosuccinic acid, ethylene diamine tetra-acetic acid, penicillamine, and succimer. Some of these chelators have been reported to adversely affect the digestive tract and bones, and cause muscle weakness while some of them spread lead to other bodily organs [18-20]. The availability of rich antioxidants and phytochemicals with proven metal chelating properties makes them good candidates for treating lead poisoning. The fact that most of these phytochemicals are present in our staple foods, vegetables, and fruits, suggests that they are safe compared to synthetic drugs and chemicals with known toxicities.

Trévo is a phytochemical-rich supplement produced in the USA. It is commercially promoted as a blood purifying, immune booster, detoxifier, and regenerating product that improves the health and well-being of individuals. Also, the anticancer, and the protective effects of trevo on the liver, heart and nervous system against various toxins have been reported [21-23]. In an earlier study, we have reported the protective activity of trévo against cyanide-induced nephrotoxicity [24]. The current study was planned to investigate the protective effect of trévo against lead-induced nephrotoxicity in male Wistar rats.

\section{Materials and Methods}

Chemicals and reagents: Lead acetate $(\mathrm{PbA}), \mathrm{Re}-$ duced glutathione, Thiobarbituric Acid (TBA), Trichloroacetic Acid (TCA), Chloro Dinitrobenzene (CDNB), and Nicotinamide Adenine Dinucleotide (NADH) were purchased from Sigma-Aldrich (Darmstadt, Germany). The kits for creatinine, urea and uric acid were obtained from Randox laboratories Ltd (Crumlin, UK). Trèvo was a product of Trèvo TM LLC (Oklahoma City, USA). All chemicals used in this study were of analytical grades.
Experimental design: Thirty-five male Wistar rats, weighing $170 \pm 10 \mathrm{~g}$, were purchased from the Central Animal House, University of Benin, Edo State, Nigeria, and were used in this study. The animals were housed in well-ventilated cages and were provided water and food ad libitum. All experimental protocols complied with the guidelines of the Helsinki Declaration of 1975.

Animals were orally administered $2 \mathrm{ml} / \mathrm{kg}$ of trévo for two days prior to co-administration with $15 \mathrm{mg} / \mathrm{kg} \mathrm{PbA}$ for 12 consecutive days. The animal groups were as follows:

Group 1: administered the vehicle (distilled water).

Group 2: administered $15 \mathrm{mg} / \mathrm{kg}$ of PbA Intraperitoneally (IP).

Group 3: orally administered $2 \mathrm{ml} / \mathrm{kg}$ of trevo before the IP administration of $\mathrm{PbA}$.

Group 4: orally administered $5 \mathrm{ml} / \mathrm{kg}$ of trevo before the IP administration of $\mathrm{PbA}$.

Group 5: orally administered $5 \mathrm{ml} / \mathrm{kg}$ of trevo only.

Processing the kidneys: $24-\mathrm{hr}$ after the last administration, animals were sacrificed by cervical dislocation and the kidneys were removed, rinsed, and homogenized in phosphate buffer saline $(0.1 \mathrm{M}, \mathrm{pH} 7.4)$, resulting in a $10 \% \mathrm{w} / \mathrm{v}$ homogenate. The homogenate was centrifuged at $15000 \mathrm{rpm}$ for $10 \mathrm{~min}$ at $4 \mathrm{oC}$ to obtain a clear supernatant that was used for the biochemical assays.

Preparation of sera: Blood samples were collected from the rats' heart by cardiac puncture into sample tubes. The blood samples were centrifuged at $3,000 \mathrm{~g}$ for $10 \mathrm{~min}$ in a MSC bench centrifuge to obtain the sera, which were used for the estimation of the rats' renal function.

Renal function biomarkers: The concentrations of urea, creatinine, and uric acid were determined in the sera following the instruction from the kits' manuals.

\section{Biochemical assays}

Estimation of oxidants in the kidneys: The level of oxidative stress was determined by measuring the amount of Malonedialdehyde (MDA) formed from Lipid peroxidation (LPO) in the kidney tissue samples according to a previously described method [25].

Estimation of antioxidants in the kidneys: The concentration of Glutathione (GSH) was measured ac- 
cording to an established method [26]. Catalase (CAT) activity was determined as described earlier [27]. The activity of Superoxide Dismutase (SOD) was measured as described by an earlier study [28].

Glutathione transferase assay: The activity of GST in the kidneys was assessed as described previously [29].

Statistical analyses: The data were analyzed statistically using GraphPad Prism 6.01 software. One way Analysis of Variance (ANOVA) was used to compare the values between groups while Duncan's multiple range test was used as descriptive. All values were expressed as the Means $\pm \mathrm{SD}$ of five animals per group. The statistical significance was considered at a minimum of $\mathrm{P}<0.05$ level.

\section{Results}

Serum markers of renal damage: Table 1 summarizes the effect of trevo and $\mathrm{PbA}$ on the serum levels of urea, creatinine, and uric acid. The exposure of the rats to $\mathrm{PbA}$ caused a significant increase in the serum levels of urea, uric acid, and creatinine as compared to those of the controls $(\mathrm{P} \leq 0.001)$. Pretreatment of the rats with either $2 \mathrm{ml} / \mathrm{kg}$ or $5 \mathrm{ml} / \mathrm{kg}$ of trevo significantly prevented the renal damage induced by $\mathrm{PbA}$ as observed by significant decreases in the serum levels of urea, creatinine, and uric acid, compared to those in the untreated animals $(\mathrm{P}<0.01-0.001)$. The administration of $5 \mathrm{ml} / \mathrm{kg}$ of trevo to the rats had no significant effect on serum levels of urea, uric acid, and creatinine, compared to those of the control animals $(\mathrm{P}>0.05)$.

Effect of lead acetate and trevo on the oxidative stress: Figure 1 shows the effect of trevo on the renal Malondialdehyde (MDA) level in the rats following exposure to $\mathrm{PbA}$. The lead acetate caused a significant increase in the kidneys' MDA level as compared to that of the control $(\mathrm{P}<0.001)$. The administration of rats with $2 \mathrm{ml} / \mathrm{kg}$ or 5 $\mathrm{ml} / \mathrm{kg}$ of trevo caused a significant decrease in the MDA concentration as compared to that of the untreated animals $(\mathrm{P}<0.001)$. The administration of $5 \mathrm{ml} / \mathrm{kg}$ of trevo to the animals had no significant effect on the MDA level as compared to that of the control animals $(\mathrm{P}>0.05)$.

Figure 2 shows the protective effect of trevo against $\mathrm{PbA}$-induced depletion of Glutathione (GSH). The exposure of rats to $\mathrm{PbA}$ resulted in a significant decline in the GSH concentration, as compared to that of the control animals $(\mathrm{P}<0.001)$. The administration of $2 \mathrm{ml} / \mathrm{kg}$ of trévo caused an insignificant increase $(\mathrm{P}<0.05)$ in GSH concentration, while treatment with $5 \mathrm{ml} / \mathrm{kg}$ caused a significant increase in GSH concentration $(\mathrm{P}<0.001)$. The administration of $5 \mathrm{ml} / \mathrm{kg}$ of trévo had no significant effect on the rats, as compared to that observed in the control animals $(\mathrm{P}>0.05)$.

Figures 3 and 4 reflect the effect of $\mathrm{PbA}$ and trevo on the activity of Catalase (CAT) and Superoxide Dismutase (SOD). Lead acetate significantly inhibited the activities of CAT and SOD in the kidney tissue samples of the rats as compared to that of the control animals $(\mathrm{P}<0.001)$. The administration of $2 \mathrm{ml} / \mathrm{kg}$ or $5 \mathrm{ml} / \mathrm{kg}$ of trevo prevented the inhibitory activities of CAT and SOD caused by $\mathrm{PbA}$ exposure. These were evident by the significant increases in the activities of CAT and $\mathrm{SOD}$, as compared to those observed in the untreated group ( $\mathrm{P}>0.05)$. The administration of $5 \mathrm{ml} / \mathrm{kg}$ of trevo had no significant effect on the CAT and SOD activities as compared to those of the control rats $(\mathrm{P}>0.05)$.

Effects on Glutathione-S-Transferase (GST) activity in the rats' kidneys: Figure 5 shows the effects of PBA and trevo on the GST activity. In these animals, $\mathrm{PbA}$ caused a significant decrease in the GST activity as compared to the that observed in the control rats $(\mathrm{P}<0.01)$. Pretreatment with $2 \mathrm{ml} / \mathrm{kg}$ or $5 \mathrm{ml} / \mathrm{kg}$ of trevo

Table 1. Serum urea, uric acid and creatinine levels in control and in all experimental groups $(n=7)$

\begin{tabular}{cccc}
\hline Groups & \multicolumn{3}{c}{ Mean \pm SD } \\
\cline { 2 - 4 } Control & Urea $(\mathbf{m g} / \mathrm{dl})$ & Uric Acid $(\mathbf{m g} / \mathrm{dl})$ & Creatinine $(\mathbf{m g} / \mathrm{dl})$ \\
\hline $15 \mathrm{mg} / \mathrm{kg} \mathrm{PbA}$ & $5.3 \pm 0.59$ & $19.8 \pm 1.70$ & $5.4 \pm 0.73$ \\
$2 \mathrm{ml} / \mathrm{kg}$ trévo+PbA & $9.8 \pm 0.43^{* * * *}$ & $54.5 \pm 5.50^{* * * *}$ & $27.1 \pm 2.17^{* * *}$ \\
$5 \mathrm{ml} / \mathrm{kg}$ trévo+PbA & $8.1 \pm 0.85^{\# \# \#}$ & $50.0 \pm 1.83$ & $23.9 \pm 1.65^{\# \#}$ \\
$5 \mathrm{ml} / \mathrm{kg}$ trévo & $6.9 \pm 0.71^{\# \# \#}$ & $42.0 \pm 2.79^{\# \# \#}$ & $13.2 \pm 1.37^{\# \# \#}$ \\
\hline
\end{tabular}

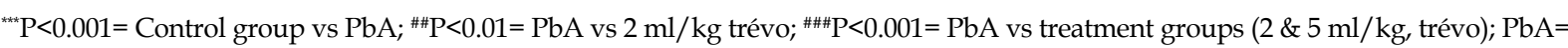
Lead acetate. 


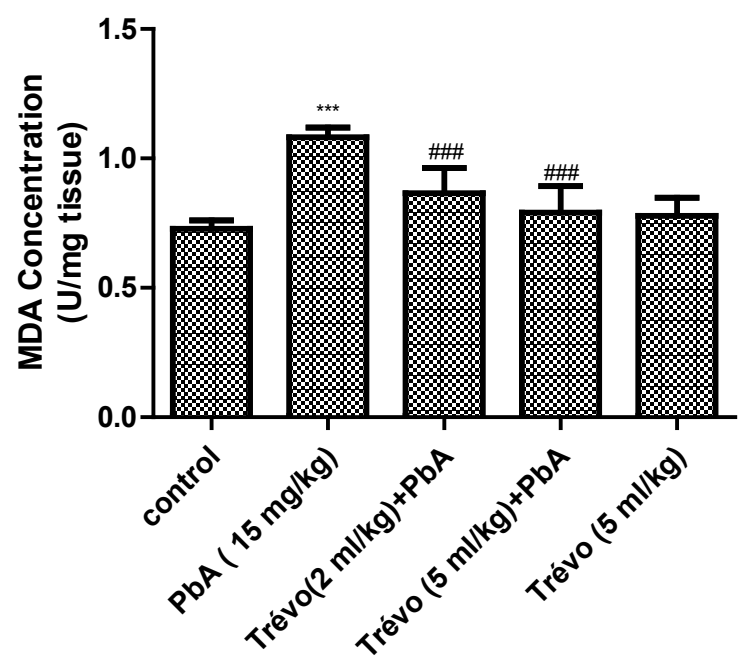

Figure 1. The concentration of lipid peroxides product Malondialdehyde (MDA), in the kidney tissue of male rats

After a 2-day oral administration of trévo and 12-day co-administration of $\mathrm{PbA}(15 \mathrm{mg} / \mathrm{kg})$ intraperitoneally. Data are shown as Means $\pm S D$ for 7 animals. Statistically significant differences were: ${ }^{*} \mathrm{P}<0.001=$ control vs $\mathrm{PbA}$; ${ }^{\# \#} \mathrm{P}<0.001=\mathrm{PbA}$ vs treatment groups (2- and $5 \mathrm{ml} / \mathrm{kg}$ of trévo). PbA: Lead acetate.

caused an insignificant increase in the GST activity compared to that of the controls $(\mathrm{P}<0.05)$.

\section{Discussion}

This study investigated the nephroprotective effect of trévo following lead acetate exposure in rats. Generally,

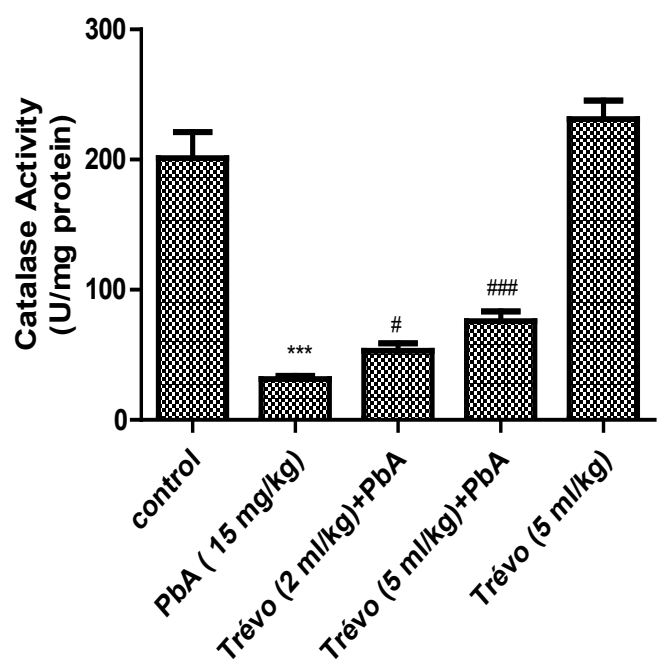

Figure 3. The catalase activity in the kidney tissue of male rats after

After 2 day- oral administration of trévo and 12-day co-administration with $\mathrm{PbA}(15 \mathrm{mg} / \mathrm{kg})$ intraperitoneally. Data are shown as Means \pm SD for 7 animals. Statistically significant differences: ${ }^{* *} \mathrm{P}<0.001=$ control vs $\mathrm{PbA}$; ${ }^{\#} \mathrm{P}<0.05=\mathrm{PbA}$ vs $2 \mathrm{ml} / \mathrm{kg}$ of trévo; \#\#\# $\mathrm{P}<0.001=\mathrm{PbA}$ vs $5 \mathrm{ml} / \mathrm{kg}$ of trévo. $\mathrm{PbA}=$ Lead acetate.

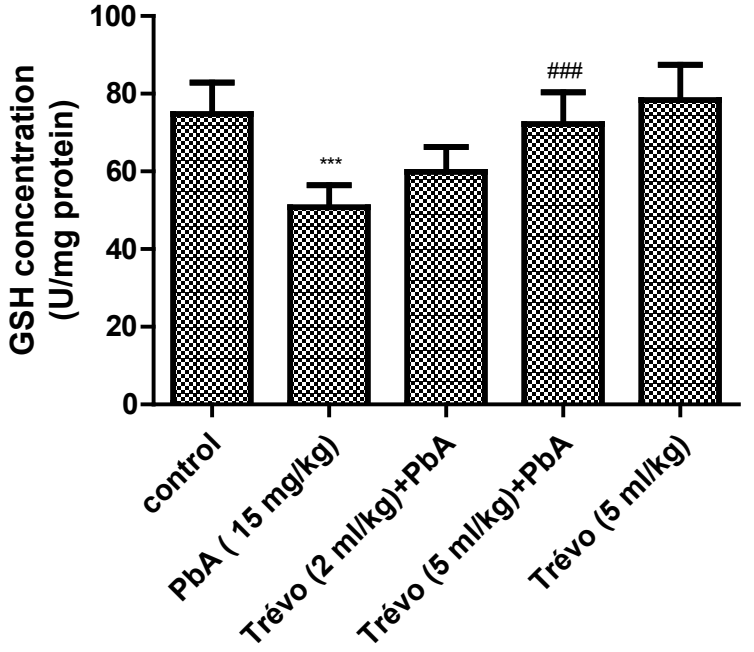

Figure 2. The concentration of non-enzymatic antioxidantreduced Glutathione (GSH) in the kidney tissue of male rats

After a 2-day oral administration of trévo and 12-day co-administration of $\mathrm{PbA}(15 \mathrm{mg} / \mathrm{kg})$ intraperitoneally. Data are shown as Means $\pm S D$ for 7 animals. Statistically significant differences: "*t" $\mathrm{P}<0.001=$ control vs $\mathrm{PbA}$; ${ }^{\# \# \# ~} \mathrm{P}<0.001=\mathrm{PbA}$ vs $5 \mathrm{ml} / \mathrm{kg}$ of trévo. $\mathrm{PbA}$ : Lead acetate.

the increased urea and creatinine levels in the blood are often linked to kidney impairment. The high concentrations of urea and creatinine in the blood after lead exposure confirm its nephrotoxic effect. The rise of urea and creatinine is primarily due to increased protein turnover and failure of the glomeruli to reabsorb and prevent their leakage into the blood [30]. Another important marker

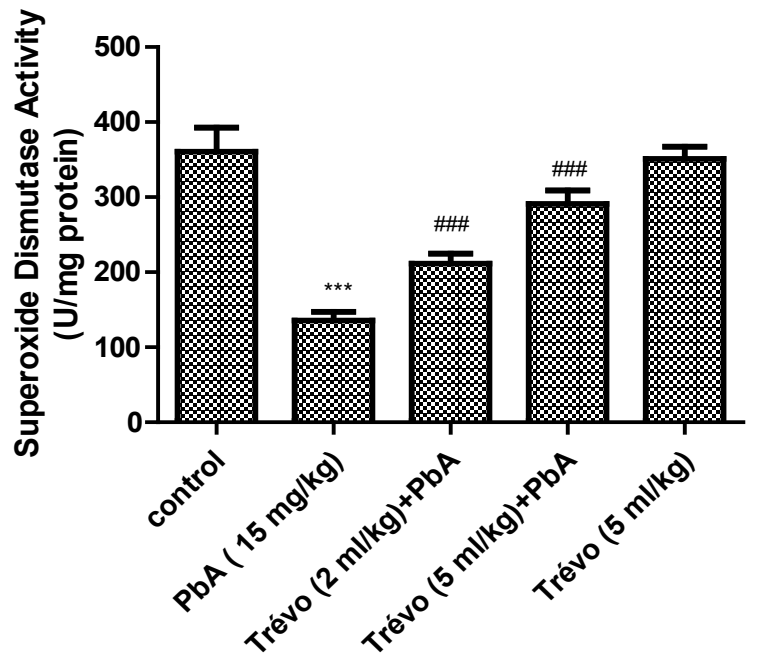

Figure 4. The Superoxide Dismutase (SOD) activity in the kidney tissue of male rats after 2 day- oral administration of trévo and 12-day co-administration with $\mathrm{PbA}(15 \mathrm{mg} / \mathrm{kg})$ intraperitoneally.

Data are shown as Means \pm SD for 7 animals. Statistically signifi-

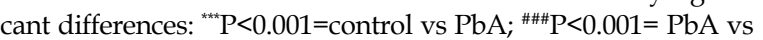
treatment groups $(5 \mathrm{ml} / \mathrm{kg}$ of trévo). $\mathrm{PbA}=$ Lead acetate. 


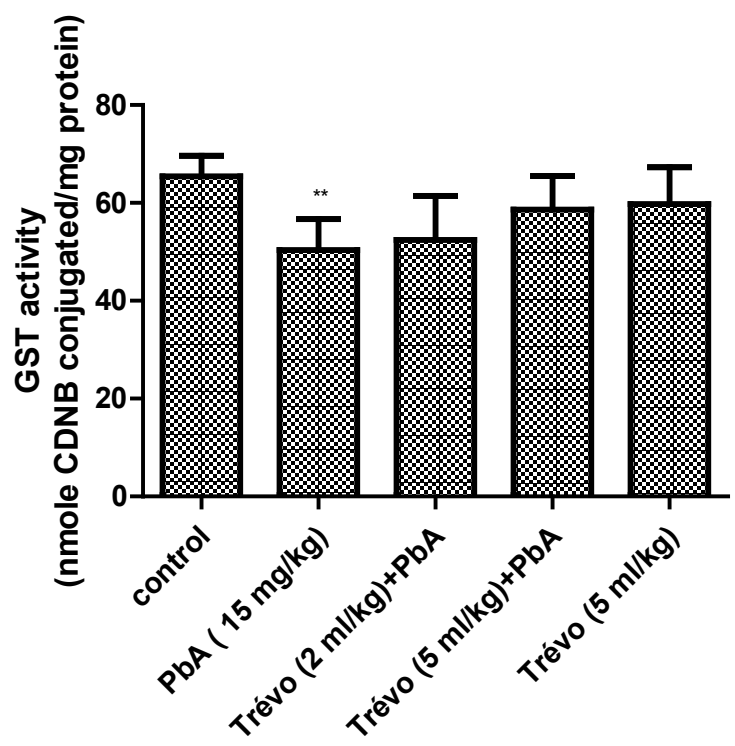

Figure 5. The Glutathione-S-Transferase (GST) activity in the kidney tissue of male rats

After 2-day oral administration of trévo and 12-day co-administration with $\mathrm{PbA}(15 \mathrm{mg} / \mathrm{kg})$ intraperitoneally. Data are shown as Mean $\pm S D$ for 7 animals. Statistically significant differences: * $\mathrm{P}<0.01=$ control vs $\mathrm{PbA} . \mathrm{PbA}=$ lead acetate.

of renal injury is the rise in uric acid in the serum, which is produced by purine metabolism. Our experimental results demonstrated that exposure to lead acetate elevated the serum uric acid level, consistent with those reported by earlier investigators [31-34].

The mechanism by which lead induces oxidative stress involves increased damages to macromolecules, such as lipids and depletion of the antioxidant system in the body [35-38]. Malondialdehyde is the most sensitive biomarker of oxidative stress, which is formed by the reaction of ROS with fatty acids [39]. The results of our experiments demonstrated that the MDA level was highly elevated in the rat kidneys after lead exposure, corroborating its role in ROS generation.

Glutathione is one of the major non-enzymatic antioxidants in the maintenance of redox status in the living organisms. Its depletion has been implicated in many diseases linked to oxidative stress. It is involved in drug metabolism, antioxidant defense, and regulation of certain cellular metabolic functions. The present study provided evidence of oxidative stress following exposure to lead as evident by the presence of low GSH concentrations in the rat kidneys. In this context, our results are similar to those reported by two earlier studies [13, 17]. They observed a significant decrease in the GSH concentration of the rats' kidneys after their exposure to lead.
Catalase (CAT) is an antioxidant enzyme widely distributed in the body. It catalyzes the conversion of hydrogen peroxide to water and oxygen. The activity of CAT is generally reduced in most organs after exposure to toxic chemicals $[11,40]$. Our results showed that lead acetate caused a significant decrease in the CAT activity in the kidneys. This enzyme is known to be protective against reactive hydroxyl radicals in animal models, and is reduced as a part of the mechanism involved in the deleterious effects of lead $[1,41]$.

Another antioxidant enzyme of significance is Superoxide Dismutase (SOD), which catalyzes the conversion of superoxide to hydrogen peroxide. Superoxide anion is one of the deadliest radicals that if not quickly eliminated, can lead to the oxidation and inactivation of various biological molecules. The reduction in SOD activity indicates a major oxidative stress. The results of the current study showed that the administration of lead acetate caused a significant decrease in the SOD activity, confirming its oxidative effect, which was consistent with the observations of earlier studies [42, 43]. Both SOD and CAT serve to clear the body of ROS, thus their reduction can be the mechanisms by which they lead to nephrotoxic alterations.

Glutathione Transferase (GST) is a conjugating enzyme involved in drug metabolism and detoxification. Its activity can be reduced due to low concentration of $\mathrm{GSH}$, toxic chemicals, or the suppressed expression of the genes involved in their synthesis. In our study, the GST activity was significantly reduced in the rats' kidney samples after exposure to lead acetate. The low GST activity can be linked to its destruction due to lead toxicity, in addition to other potential factors. Our experimental results indicated that there was a significant decrease in the kidneys' GST concentration induced by the lead toxicity. This molecule is critical in the antioxidant defense. It helps in the detoxification of xenobiotics and protection against oxidative stress $[44,45]$.

Treatment with trevo five days prior to exposure to the lead acetate reduced the serum concentrations of urea, creatinine, and uric acid, and caused a noticeable improvement in the kidneys function. In addition, the trevo treatment also reduced the kidney concentration of MDA, and increased the GSH, CAT, SOD, and GST concentrations. The nephroprotective activity of trevo against lead toxicity can be linked to the presence of various antioxidant phytochemicals in that product. Plants rich antioxidant have been effective in countering lead toxicity, since they serve as metal chelators, radical scavengers and terminator of various oxidative processes $[1,4,13,17,39,42,46]$. 


\section{Conclusion}

The pretreatment with trévo was able to prevent the leakage of molecules confined to the rats' kidneys into their sera due to exposure to lead acetate. Further, trévo at $5 \mathrm{ml} / \mathrm{kg}$ was able to limit the alteration in redox homeostasis against the adverse effects of lead acetate on the kidneys of the rats. Though it had minimal effect on GST, overall, trévo at the $5 \mathrm{ml} / \mathrm{kg}$ dosage was effective as a nephroprotective product in combating the oxidative damage induced by lead toxicity. The antioxidant activity is likely to be linked to the presence of bioactive compounds in trevo.

Limitations of the study: One of our challenges was the lack of resources to conduct morphological changes in the kidney tissues, quantification of lead in the blood and the tissue samples of the treated rats, and the molecular mechanisms of the protective effects of the trévo.

Recommendations for future studies: Further studies are recommended to investigate the protective effect of trévo on other organ tissues damaged by lead acetate.

\section{Ethical Considerations}

\section{Compliance with ethical guidelines}

All of the rats used in this study were healthy and treated according to the guidelines of the Helsinki Declaration of 1975 for the care and use of laboratory animals. The experimental design was approved by the ethics committee on Animal Research and Treatment (ART) of the Federal University Otuoke, Nigeria (Code: ART2021005). In specific terms, the experiments were conducted in the animal house of the Department of Biochemistry, Faculty of Science, Federal University Otuoke between February and June 2021.

\section{Funding}

The project was self-funded only, as part of ongoing research on pharmacological activity of Trevor.

\section{Authors' contributions}

Both authors contributed equally in the development of the manuscript.

\section{Conflict of interest}

The authors declared no conflict of interest.

\section{References}

[1] Albarakati AJA, Baty RS, Aljoudi AM, Habotta OA, Elmahallawy EK, Kassab RB, et al. Luteolin protects against lead acetateinduced nephrotoxicity through antioxidant, antiinflammatory, antiapoptotic, and Nrf2/HO1 signaling pathways. Mol Biol Rep. 2020; 47(4):2591-603 [DOI:10.1007/s11033-020-05346-1] [PMID]

[2] Abdel Moneim AE, Dkhil MA, Al-Quraishy S. The protective effect of flaxseed oil on lead acetate-induced renal toxicity in rats. J Hazard Mater. 2011; 194:250-5 [DOI:10.1016/j.jhazmat.2011.07.097] [PMID]

[3] Wu X, Cobbina SJ, Mao G, Xu H, Zhang Z, Yang L. A review of toxicity and mechanisms of individual and mixtures of heavy metals in the environment. Environ Sci Pollut Res. 2016; 23(9):8244-59 [DOI:10.1007/s11356-016-6333-x] [PMID]

[4] Soussi A, Gargouri M, Akrouti A, El Feki A. Antioxidant and nephroprotective effect of Juglans regia vegetable oil against leadinduced nephrotoxicity in rats and its characterization by GCMS. EXCLI J. 2018; 17:492-504. [DOI:10.17179/excli2018-1235] [PMID] [PMCID]

[5] Ibrahim NM, Eweis EA, El-Beltagi HS, Abdel-Mobdy YE. Effect of lead acetate toxicity on experimental male albino rat. Asian Pac J Trop Biomed. 2012; 2(1):41-6. [DOI:10.1016/S22211691(11)60187-1] [PMID] [PMCID]

[6] Markowitz M. Lead poisoning. In: Kliegman RM, Stanton BMD, St. Geme J, Schor NF, Behrman RE, editors. Nelson Textbook of Pediatrics. Philadelphia: Saunders; 2011. p. 2448-53. [DOI:10.1016/B978-1-4377-0755-7.00702-8]

[7] Alhusaini A, Fadda L, Hasan IH, Zakaria E, Alenazi AM, Mahmoud AM. Curcumin ameliorates lead-induced hepatotoxicity by suppressing oxidative stress and inflammation, and modulating Akt/GSK-3 signaling pathway. Biomolecules. 2019; 9(11):702-18. [DOI:10.3390/biom9110703] [PMID] [PMCID]

[8] Brzoska MM, Moniuszko-Jakoniuk J. Low-level exposure to cadmium during the lifetime increases the risk of osteoporosis and fractures of the lumbar spine in the elderly: Studies on a rat model of human environmental exposure. Toxicol Sci. 2004; 82(2):468-77. [DOI:10.1093/toxsci/kfh275] [PMID]

[9] de Kok TM, Hogervorst JG, Briedé JJ, van Herwijnen MH, Maas LM, Moonen EJ, et al. Genotoxicity and physicochemical characteristics of trac-related ambient particulate matter. Environ Mol Mutagenesis. 2005; 46(2):71-80. [DOI:10.1002/em.20133] [PMID]

[10] Alissa EM, Ferns GA. Heavy metal poisoning and cardiovascular disease. J Toxicol. 2011; 2011:870125. [DOI:10.1155/2011/870125] [PMID] [PMCID]

[11] Singh Z, Chadha P, Sharma S. Evaluation of oxidative stress and genotoxicity in battery manufacturing workers occupationally exposed to lead. Toxicol Int. 2013; 20(1):95-100. [DOI:10.4103/0971-6580.111550] [PMID] [PMCID]

[12] Guimarães D, Carvalho ML, Geraldes V, Rocha I, Cerqueira Alves L, Paulo Santos J. Lead in liver and kidney of exposed rats: Aging accumulation study. J Trace Elem Med Biol. 2012; 26(4):285-90. [DOI:10.1016/j.jtemb.2012.02.006] [PMID]

[13] Mohamed NB, Mohamed AH, Abu-Aita NA, Nasr SM, Nassar SA, Ahmed KA. Moringa oleifera leaf ethanol extract ameliorates lead-induced hepato-nephrotoxicity in rabbits. Asian Pac J Trop Biomed. 2020; 10(6):263-72. [DOI:10.4103/22211691.283940 
[14] Apaydın FG, Bas H, Kalender S, Kalender Y. Subacute effects of low dose lead nitrate and mercury chloride exposure on kidney of rats. Environ Toxicol Pharmacol. 2016; 41:219-24. [DOI:10.1016/j.etap.2015.12.003] [PMID]

[15] Mabrouk A, Salah IBH, Chaieb W, Ben Cheikh H. Protective effect of thymoquinone against lead-induced hepatic toxicity in rats. Environ Sci Pollut Res. 2016; 23(12):12206-15. [DOI:10.1007/s11356-016-6419-5] [PMID]

[16] Haouas Z, Zidi I, Sallem A, Bhour R, Ajina T, Zaouali M, et al. Reproductive toxicity of lead acetate in adult male rats: Histopathological and cytotoxic studies. J Cytol Histol. 2015; 6(1):1000293. [DOI:10.4172/2157-7099.1000293]

[17] Alcaraz-Contreras Y, Mendoza-Lozano RP, MartınezAlcaraz ER, Martínez-Alfaro M, Gallegos-Corona MA, Ramírez-Morales MA, et al. Silymarin and dimercaptosuccinic acid ameliorate lead-induced nephrotoxicity and genotoxicity in rats. Hum Exp Toxicol. 2016; 35(4):398-403. [DOI:10.1177/0960327115591373] [PMID]

[18] Al Omar SY. The neuroprotective role of coenzyme Q10 against lead acetate-induced neurotoxicity is mediated by antioxidant, anti-inflammatory and anti-apoptotic activities. Int J Environ Res Public Health. 2019; 16(16):e2895. [DOI:10.3390/ ijerph16162895] [PMID] [PMCID]

[19] Abdel Moneim AE. Indigofera oblongifolia prevents lead acetate-induced hepatotoxicity, oxidative stress, fibrosis and apoptosis in rats. PLoS ONE. 2016; 11(7):e0158965. [DOI:10.1371/ journal.pone.0158965] [PMID] [PMCID]

[20] Flora SJ, Pachauri V. Chelation in metal intoxication. Int J Environ Res Public Health. 2010; 7(7):2745-88. [DOI:10.3390/ ijerph7072745] [PMID] [PMCID]

[21] Akinmoladun AC, Oguntunde KO, Owolabi LO, Ilesanmi $\mathrm{OB}$, Ogundele JO, Olaleye MT, et al. Reversal of acetaminophen-generated oxidative stress and concomitant hepatotoxicity by a phytopharmaceutical product. Food Sci Hum Wellness. 2016; 6(1):20-7. [DOI:10.1016/j.fshw.2016.11.001]

[22] Ilesanmi OB, Atanu FO, Odewale TT, Adeogun E, Chikere $\mathrm{BN}$, Alaneme CU, et al. Effect of a phytonutrient-rich product and administration time on cyanide-induced cardiotoxicity. Trop J Nat Prod Res. 2020; 4(7):304-9 [DOI:10.26538/ tjnpr/v4i7.9]

[23] Ilesanmi OB and Ikpesu T. Neuromodulatory activity of trèvo on cyanide-induced neurotoxicity viz neurochemical, antioxidants, cytochrome $\mathrm{C}$ oxidase and p53. Adv Tradit Med. 2021; 21(2):297-304. [DOI:10.1007/s13596-020-00450-w]

[24] Ilesanmi OB, Asaba A. Ameliorative effect of a multi-nutrient-rich product against cyanide induced hepatorenotoxicity. Drug Discovery. 2021; 15(35):51-9. https://discoveryjournals. org/drugdiscovery/current_issue/2021/v15/n35/A3.htm

[25] Varshney R, Kale RK. Effects of calmodulin antagonists on radiation-induced lipid peroxidation in microsomes. Int $\mathrm{J}$ Radiat Biol. 1990; 58(5):733-43. [DOI:10.1080/09553009014552121] [PMID]

[26] Jollow DJ, Mitchell JR, Potter WZ, Davis DC, Gillette JR, Brodie BB. Acetaminophen-induced hepatic necrosis. II. Role of covalent binding in vivo. J Pharmacol Exp Ther. 1973; 187(1):195-202. [PMID]

[27] Aebi H. Catalase. Methods Enzyma Anal. 1974; 2:673-84 [DOI:10.1016/B978-0-12-091302-2.50032-3]
[28] Habig WH, Pabst MJ, Jakoby WB. Glutathione S-transferases: The first enzymatic step in mercapturic acid formation. J Biol Chem. 1974; 249(22):7130-9. [DOI:10.1016/S00219258(19)42083-8] [PMID]

[29] Misra HP, Fridovich I. The univalent reduction of oxygen by reduced flavins and quinones. J Biol Chem. 1972; 247(1):188-92. [DOI:10.1016/S0021-9258(19)45773-6] [PMID]

[30] Ruilope LM, Garcia-Puig J. Hyperuricemia and renal function. Curr Hypertens Rep. 2001; 3(3):197-202. [DOI:10.1007/ s11906-001-0038-2] [PMID]

[31] Hasanein P, Teimuri-Far M. Protective effect of bioactive peptide carnosine against lead-induced oxidative stress in kidney of rats. Cell Mol Biol (Noisy-le-grand). 2015; 61(4):8-14. [PMID]

[32] Makena W, Otong ES, Dibal NI, Ishaku B, Bazabang SA. Aqueous fruit pulp extract of Adansonia digitata (L) protects against lead-acetate-induced hepato-renal damage in rat model. Beni-Suef Univ J Basic Appl Sci. 2021; 10(1):1-7. [DOI:10.1186/s43088-021-00151-6]

[33] Alhusaini AM, Fadda LM, Hasan IH, Ali HM, Badr A, Elorabi N, et al. Role of some natural anti-oxidants in the down regulation of Kim, VCAM1, Cystatin C protein expression in lead acetate-induced acute kidney injury. Pharmacol. Rep. 2020; 72(2):360-7. [DOI:10.1007/s43440-020-00072-8] [PMID]

[34] Hasanein, P, Riahi H. Preventive use of berberine in inhibition of lead-induced renal injury in rats. Environ Sci Pollut Res. 2018; 25(5):4896-903. [DOI:10.1007/s11356-017-0702-y] [PMID]

[35] Patrick L. Lead toxicity part II: The role of free radical damage and use of antioxidants in the pathology and treatment of lead toxicity. Altern Med Rev. 2006; 11(2):114-27. [PMID]

[36] Hussein SA, Mohammed RR, Ali AH, Protective effects of alpha-lipoic acid against lead-induced oxidative stress in erythrocytes of rats. Benha Vet Med J. 2014; 27(2):382-95. https://www.bvmj.bu.edu.eg/issues/27-2/38.pdf

[37] Xu J, Lian LJ, Wu C, Wang XF, Fu WY, Xu LH. Lead induces oxidative stress, DNA damage and alteration of p53, Bax and Bcl-2 expressions in mice. Food Chem Toxicol. 2008; 46(5):1488-94. [DOI:10.1016/j.fct.2007.12.016] [PMID]

[38] Mervat HG, Nabela IE, Mohamed MAH, Gihan GM. Efficacy of curcumin on lead induced nephrotoxicity in female albino rats. J Am Sci. 2012; 8(6):78-82. https:/ / www.researchgate.net/profile/Mohamed-Hussein-77/publicationRats.pdf

[39] Sudjarwo SA, Eraiko K, Sudjarwo GW, Koerniasari. Protective effects of piperine on lead acetate induced-nephrotoxicity in rats. Iran J Basic Med Sci. 2017; 20(11):1227-31. [DOI:10.22038/IJBMS.2017.9487] [PMID] [PMCID]

[40] Bennet C, Bettaiya R, Rajanna S, Baker L, Yallapragada $\mathrm{PR}$, Brice JJ, et al. Region-specific increase in the antioxidant enzymes and lipid peroxidation products in the brain of rats exposed to lead. Free Radical Res. 2007; 41(3):267-73. [DOI:10.1080/10715760600889855] [PMID]

[41] Udensi UK, Tchounwou PB. Dual effect of oxidative stress on leukemia cancer induction and treatment. J Exp Clin Cancer Res. 2014; 33:106. [DOI:10.1186/s13046-014-0106-5] [PMID] [PMCID]

[42] Gargouri M, Soussi A, Akrouti A, Magné C, El Feki A. Ameliorative effects of Spirulina platensis against lead induced 
nephrotoxicity in newborn rats: Modulation of oxidative stress and histopathological changes. Excli J. 2018; 17:215-32. [DOI:10.17179/excli2017-1016] [PMID] [PMCID]

[43] Soussi A, Abdennabi R, Ghorbel F, Murat JC, El Feki AF. Ameliorated effects of (-)-Epigallocatechin Gallate against toxicity induced by vanadium in the kidneys of Wistar rats. Biol Trace Elem Res. 2017; 180(2):239-45. [DOI:10.1007/ s12011-017-1004-4] [PMID]

[44] Casalino E, Sblano C, Landriscina V, Calzaretti G, Landriscina C. Rat liver glutathione S-transferase activity stimulation following acute cadmium or manganese intoxication. Toxicology. 2004; 200(1):29-38 [DOI:10.1016/j.tox.2004.03.004] [PMID]

[45] Liu B, Zhang H, Tan X, Yang D, Lv Z, Jiang H, et al. GSPE reduces lead-induced oxidative stress by activating the Nrf2 pathway and suppressing miR153 and GSK-3 $\beta$ in rat kidney. Oncotarget. 2017; 8(26):42226-37. [DOI:10.18632/oncotarget.15033] [PMID] [PMCID]

[46] Kwon SY, Bae ON, Noh JY, Kim K, Kang S, Shin YJ, et al. Erythrophagocytosis of lead-exposed erythro cytes by renal tubular cells: Possible role in lead-induced nephrotoxicity Environ Health Perspect. 2015; 123(2):120-7. [DOI:10.1289/ ehp.1408094] [PMID] [PMCID] 